\title{
Challenges and contributions of women workers in the agricultural sector in the Sibaté region
}

\section{Retos y aportes de las mujeres trabajadoras del sector agro en la región Sibaté}

Victor Enrique Bonilla

Ph.D, Corporación Universitaria Minuto de Dios, Soacha - Colombia, https://orcid.org/0000-0002-3278-145X victorbonillacastillo@gmail.com

Karen Jullieth Hernández Sarmiento

Ph.D, Corporación Universitaria Minuto de Dios, Soacha - Colombia, https://orcid.org/0000-0003-4290-1758, karenh@uniminuto.edu.co

Geraldinne Rodríguez Bedoya

Ph.D., Corporación Universitaria Minuto de Dios, Soacha - Colombia https://orcid.org/0000-0002-1696-2066, grodri62@uniminuto.edu.co

\section{Abstract}

The flower industry appears forty years ago in fields dedicated to agriculture in the savannah of Bogota as Madrid, Mosquera and Funza among others, in these forty years of activity in the flower sector grew and became the fourth largest industry in the country. In 1995, the export of flowers to foreign countries began. One of the most relevant factors of floriculture is its human capital, most of which are women who are massively hired due to qualities such as gentleness, patience and the low salary they are willing to receive for the work they perform.

\section{Resumen}

La industria floricultora aparece cuarenta años atrás en campos dedicados a la agricultura en la sabana de Bogotá como Madrid, Mosquera y Funza entre otros, en estos cuarenta años de actividad en 
el sector floricultor creció y se convirtió en la cuarta industria del país. En el año de 1995 se inicia la exportación de flores a países extranjeros, uno de los factores más relevantes de la floricultura es su capital humano que en su gran mayoría son mujeres que son contratadas masivamente debido a cualidades como la delicadeza, la paciencia y el bajo salario que están dispuestas a recibir por las labores que desempeñan.

\section{Palabras clave/ Keywords}

Floriculture, Women, Labor Exploitation, Illness, Crops, Economy

Floricultura, Mujeres, Explotación Laboral, Enfermedad, Cultivos, Economía.

\section{Introduction}

The following research is based on a study conducted in the floricultural business sector of the country, which is currently positioned as the fourth most important sector in terms of exports, and has been enjoying a healthy economy and progressive growth for forty years. For Ortiz (2014) and Berbegal-Bolsas et al., (2021) the focus of this research is not oriented to make an analysis of the success obtained by this business sector, but to expose the working conditions of the workers who with their effort and dedication have contributed to position this industry in the place of importance it has today; but however, despite its great success and economic growth none of these benefits seem to improve the quality of life of these workers of such an important economic sector of the country.

Today, almost thirty years after the 1991 Constitution came into force, whose main objective is to ensure the welfare and dignity of all Colombians, Article 25 stipulates that "Work is a right and a social obligation and enjoys, in all its forms, the special protection of the State. Everyone has the right to work in dignified and fair conditions" (p. 25). However, many of the workers in this sector have quite unfavorable working conditions.

To (López-Rodríguez, 2018, p. 92) contextualize and understand the problem in its full dimension, first a brief historical account of what has been the development and growth of this sector in the country will be made, also Zuluaga \& Moncayo (2014) indicate that later we will talk about the working conditions in which the workers of this sector are found, taking as a reference the flower crops located in the 
municipality of Sibaté Cundinamarca; ending with an approach from the point of view of the business administration on how to mitigate this harsh and hard reality that women who work in this sector face on a daily basis, in order to provide them with decent working conditions.

According to Arza et al, (2021); Cárdenas and Rodríguez (2011) the flower industry appeared forty years ago in the fields dedicated to traditional agriculture and livestock in municipalities of the savannah of Bogotá, such as: Madrid, Mosquera, Funza, Tenjo, Chía and some municipalities of eastern Antioquia, which were gradually covered with plastics giving way to what would soon become one of the main agro-industries in the country, generating foreign exchange and employing mostly unskilled labor.

Miranda \& Corica (2015) comment that in 1995 the export of flowers to foreign countries began. Due to the accelerated growth of 16 floriculture, Colombia became the second largest exporter of flowers in the world, after Holland, and the main exporter to the United States.

The world's main flower exporters produced U\$7,853 million, including the Netherlands (40\%), Colombia (17\%) and Ecuador (11\%). Among the world's main importers are the USA, Germany and the United Kingdom, with $16 \%, 15 \%$ and $13 \%$, respectively. One of the main destination markets for flowers produced in Colombia is the United States, with $77 \%$, and the United Kingdom and Japan, each with a $4 \%$ share.

Cardenas and Rodriguez (2011) also state that:

"In these 40 years of activity of the flower sector grew and became the fourth largest industry in the country behind oil, mining and coffee and at the end of the first decade of the XXI century exports fluctuated between 900 and 1,000 million dollars generating about 100,000 direct jobs mostly of operators" p. 15 .

As can be seen above, the floriculture sector has been enjoying good financial health and productive and economic growth that has led it to position itself as one of the leading export sectors at the national level. From the point of view of business administration, this means a substantial profit margin for entrepreneurs. However, this is a clear sign that economic growth and business development does not mean welfare and social development for the workers in this industry. 
In addition to the low salaries, which in some cases are not even close to the legal minimum wage stipulated by the national government, these employees must face with stoic patience the labor harassment since they are often forced to extend their working day, especially in times where international and national trade are in high demand, such as Valentine's Day, Mother's Day, Love and Friendship Day in the case of Colombia, in order to meet market demands: Valentine's Day, Mother's Day, Day of Love and Friendship in the Colombian case in order to meet the demands of the market and all for a meager overtime pay that does not compensate the effort and physical wear of a longer working day. In this regard, Cactus (2013), states that:

"The flower sector wants to generate higher profits. They demand greater productivity in terms of their daily goals in order to export more, which many of these workers cannot oppose: it is their daily sustenance and, since they do not have the requirements to access other types of employment, it is their only and indisputable source of income. In addition to the imperative need to find income to survive for themselves and their families, most of the workers are clearly unaware of their labor rights and social guarantees. Most are unaware of the legal norms that regulate labor in Colombia, much less how to enforce them." p. 12.

In addition to the low salaries and the hard working hours that women workers in the flower sector must perform, there are other types of affectations that contribute to further diminish the quality of life of these poor women, such as, first of all, the serious deterioration of their health and, secondly, the few labor guarantees offered by their employers.

Tabet (2017) mentions that the floricultural work has all occupational risks such as: physical problems related to work ergonomics (repetitive handling of tweezers and scissors to remove pine needles and model the flowers; chemical due to the increasing use of pesticides in charge of accelerating production and which are harmful to the health of the people who work there; biological due to the work with plants and contact with various types of microbes; psycho-social due to the high level of stress due to work under pressure and for times); without forgetting the exposure to excessive cold and heat.

The National Safety Institute talks about The application of pesticides in the cultivation process is carried out in closed enclosures or 
greenhouses. The most common methods of this application are: spraying of liquids and fogging or distribution of mists, dusts, vapors, fumes, aerosols and granules. In all of them there is a risk of exposure and the most frequent routes of exposure for flower growers are cutaneous and respiratory, the activity is characterized by intense and frequent contact with flowers and plants and, therefore, with primary irritants or allergenic substances (for this reason it is important to promote and adopt the use of gloves) as well as exposure to pollen and the scent of certain flowers and decorative plants. Musculoskeletal disorders such as tendinitis of the elbow and wrist, carpal tunnel syndrome and alterations in the mobility of the shoulders are frequent.

These are the battles that flower growers fight every day as they expose themselves to bring a daily sustenance to their homes, and although in the eyes of an unsuspecting spectator it would seem that they are lucky to be surrounded by roses, for Morteruel et al. (2021) and Núñez, (2017) the crude and ignored reality is that they really live among thorns. Moreover, the health problems they suffer transcend their own corporeality and affect the health and well-being of their children.

Pesticides used in the flower industry have future effects on babies born to flower-growing mothers; these children develop communication difficulties, less fine motor skills and are five times more likely to have visual problems than children of mothers in other occupations.

As already mentioned, the flower industry operators are being recruited from a sector of the country's female population that is in a sensitive state of social vulnerability due to various circumstances. Added to this are the high unemployment rates in the nation, the armed conflict that has displaced a considerable number of the rural population to the urban centers, especially in the main cities, causing poverty belts to grow in their peripheries and therefore a healthy reserve of labor for the business sector and especially for the flower industry. All these factors have contributed to labor abuse by employers in this economic sector. Despite the fact that the flower industry is growing more and more, workers do not obtain better benefits or labor guarantees, on the contrary, their working conditions are increasingly precarious, as can be seen in an article of the magazine florecer in its 26th edition where it is explained that:

The most acute impairment of working conditions lies in work overload. The work system is manual, management is despotic, and 
productivity increases depend directly on increased muscular and nervous effort. The "incentives" consist of competition among operators, harassment by supervisors, public embarrassment of laggards, and threats of dismissal or non-renewal of contract. The strenuous extension of the workday as a way to meet goals in seasons such as Valentine's Day is often not compensated in money but in time, or is simply withheld. Such a degree of subjugation of the workers is antagonistic to any form of organization or exercise of rights.

What is mentioned in the previous paragraph becomes a bleak outlook for women who work in this sector, because no matter how much the economy and the flower industry grow in the country, they continue to be marginalized and the importance of their labor force for the growth of this industry is ignored.

Thus, the main objective of this research is to identify the challenges and contributions of women working in the flower-growing sector of agriculture in Sibaté. With them, the following specific objectives are followed: To evidence the labor problems of women floriculturists in the municipality of Sibaté Cundinamarca; To understand the negative impact that bad cultivation practices have on the health of women floriculturists; and To analyze the vulnerability of women who dedicate their main work to floriculture in the municipality of Sibaté Cundinamarca.

Chiavenato (2009) and Richter, (2013) emphasize that the worker should no longer be seen as a resource of the organization, as servile objects or simple passive subjects of the process, but fundamentally as active subjects who make decisions, take actions, create innovations and add value to organizations. Moreover, the person is seen as a proactive agent, endowed with his or her own vision and, above all, intelligence, which is the greatest of human abilities, the most advanced and sophisticated.

Regardless of what the theoreticians may say about humanizing relations in production systems between employers and employees, no matter how much they highlight the sensitivity and the invaluable value of human resources in the business sector, the indisputable and paradoxical truth is that in the XXI century where politicians and different social sectors proudly proclaim that we are a society of rights that ensures the dignity and welfare of all human beings without distinction of race, creed or social status, the dignity and rights of women workers in the flower sector continue to be violated in such a 
flagrant manner; the dignity and rights of women workers in the flower sector continue to be violated in such a flagrant manner. But perhaps the most outrageous thing is that the companies in this sector forty years later have not even been able to make a substantial investment in equipment to at least as far as possible mitigate the health problems of their workers who are exposed every day to breathe different chemical compounds, pollen and other things in the closed environment of a greenhouse, not to mention the issue of humidity and sudden changes in temperature when entering and leaving their workplace.

Female participation in the floriculture industry is $65 \%$ higher than that of men, but why the massive hiring of female personnel? According to Olmos-Suarez, (2018) this is because women floriculturists clean weeds, tie plants, prune, cut, harvest and pack for a much lower wage value than what a man charges, men are more involved in tasks such as irrigation, fumigation and crop maintenance.

Other authors such as Garzón and Pedraza (2013) state that the reason for the majority hiring of women finds different answers depending on who is asked. It is argued that this preference is related to certain qualities considered feminine, such as care, delicacy, dexterity or patience, which allow a better job to be done. On the other hand, several studies document how women are more dependent on this source of work: most of the operators are mothers who are heads of households.

Although occupational disease is something that has always affected human talent and therefore business productivity, in recent decades measures have been taken to minimize this problem either by providing equipment to operators or by training personnel in occupational health issues. As it has been evidenced, the floriculture industry does not escape from this scourge, since a high percentage of women are affected in their health as a result of this occupation; however, the hypothesis that we intend to handle in this work is not only about the causes of this health problem in the floricultural sector of the country, but also about the apathy on the part of the entrepreneurs of this sector towards the welfare of their human resources, which is basically due to three aspects, namely:

a) Women workers in the floriculture sector are a type of worker that does not require a high degree of specialization, which makes them an easily replaceable resource for the companies. 
b) Companies in the floriculture sector are not adequately implementing education programs for their personnel regarding occupational hazards, since their human capital is easily renewable (business negligence to save time and money).

c) Companies in the floriculture sector are not adequately equipping their human talent with the protective gear required by their employees for this type of work, which in the administrative sector is known as saving on production costs.

In the midst of this not very encouraging hypothesis, it should be noted that in Colombia the success of the floriculture sector depends largely on human capital, most of which is made up of women. According to Cantor (2003), the flower industry arrived in Colombia at the end of the 1960s. A North American promoted the first cultivation of flowers in the country, which today is the world's second largest exporter of 21 this product, recognized for its variety and quality. According to the Asociación Colombiana de Floricultores, this industry generates large amounts of foreign exchange for the nation and benefits the population by creating direct jobs with minimal training requirements that are not very demanding in terms of hired labor.

On the other hand, Cactus (2013) states that: "its workers, however, have poorly paid jobs, precarious working conditions that cause damage to their health" (p. 23). The working hours of the employees in this industry are very long because they are obliged to meet certain goals that are almost impossible to achieve in the established working hours, which is why their working hours are extended.

As this is an investigative work carried out with a sample taken from the floricultural sector of the municipality of Sibate, some tools have been used such as the interview, the survey and the field observation, as follows a brief description of the importance of each one of them in the elaboration of this work.

\section{Materials and Methods}

An interview is an exchange of ideas and opinions through a conversation that takes place between one, two or more people where an interviewer is designated to ask questions. The importance of this tool lies in the fact that it allows us to know first hand information with the actors who are directly involved in the research process. The following are the findings of a survey of 44 women workers in the flower sector. 


\section{Results}

Of the women working in floriculture, $79.5 \%$ said that they have been working in this sector for approximately 2 months to a year; only $13.6 \%$ of the women surveyed said that they had been working for a period of between 2 and 5 years, and a small percentage of $6.9 \%$ said that they had been working for 5 years or more. It is clear from these percentages that this is a sector that has a high turnover of personnel, and many of the respondents who say they have been working in this industry for several years, make the point that they have not worked in a single flower crop, which corroborates what was said in previous paragraphs that this is one of the jobs that offers the least job stability.

Regarding wages, the answer to this question from the women growers was that $68.1 \%$ of them earn less than the legal minimum wage and only $31.8 \%$ of them earn the minimum wage that should be paid to any worker. This minimum wage for them is earned by also counting their overtime. And they say that the management of the flower companies takes advantage of them because they are not educated and in many cases are mothers who are heads of household.

Regarding the issue of additional economic incentives or emotional salaries provided by the company, $100 \%$ of the women floriculturists said that they had never received additional incentives for the effective fulfillment of their work, and stated that this leads them not to want to excel in their jobs, but to dedicate themselves to doing the work for which they are paid.

The $98 \%$ of women floriculturists say they feel exploited at work in this industry, a fairly large figure, while only $2 \%$ of them say the opposite, and this is really due to a lack of knowledge of their labor rights.

$100 \%$ of the women floriculturists interviewed reiterated that they would like to have a permanent employment contract, with all the legal benefits and guarantees that workers should have for themselves and their families.

\section{Conclusions}

By way of conclusion with this research work it has been observed that in the country there is no effective control by government entities for the protection of the labor rights of the less favored classes and even 
more marked this situation is seen in front of the abandonment by the state towards the working classes of agriculture shows that this is an old problem in our territory can be seen with the massacre of the banana plantations and the recent agrarian strikes, A clear example is presented by the magazine Semana (2014), which states that Colombia is one of the worst countries to work in because workers' rights are not respected. This conclusion was reached by the International Trade Union Confederation (ITUC), an alliance of regional trade confederations that advocates for labor rights around the world. In this index Colombia is on a par with China and worse than Haiti with a score of 5 . It is essential to empower the human talent of the flower sector so that their contributions to society and the economy become visible, in this way it will be possible to build strong sectors. She comments that female empowerment is built on the idea of selfefficacy and the importance of the realization of women, in terms of the objective of being agents of change in their own lives; we must try to make visible the leading role of these women and the importance of their actions in this sector.

A possible solution to this problem would be to establish a regulation by the governmental entities so that the hiring systems in the agricultural sector are made in a counter current way offering stable jobs that allow the worker to have all the benefits that by law should correspond to him as the vast majority of collaborators who work in occupations other than those of the Colombian agricultural sector. In addition to recognizing the contribution that these workers make with their efforts to the economic growth of the country and the strengthening of Colombian companies so that they continue exporting quality products and this nation is recognized for it worldwide.

\section{References}

Arza, J., Carrón, J., \& Rodríguez, M. F. (2021). Dietary patterns of Roma population and total population in Spain. Gaceta Sanitaria, $x x$. https://doi.org/10.1016/j.gaceta.2021.04.002

Berbegal-Bolsas, M., Gasch-Gallén, Á., Oliván-Blázquez, B., Porroche-Escudero, A., Fueyo-Díaz, R., \& Magallón-Botaya, R. (2021). Validation of the Spanish version of Feminism and the Women's Movement Scale in university students. Gaceta Sanitaria, $x x$, 2-5. https://doi.org/10.1016/j.gaceta.2021.02.011 
Cactus. (2013). Flower exploitation in Colombia; working among roses living among thorns. Retrieved from http://www.revistapueblos.org/blog/2013/o2/14/explotacionde-flores-en-colombia-trabajando-entre-rosas-viviendo-entreespinas/

Cantor, M. (2003). Labor rights of women in the flower industry in Bogotá. Retrieved from http://base.d-ph.info/es/fiches/premierdph/fiche-premierdph-6498.html

Cardenas, M and Rodriguez Y. (2011). Study of the flower agroindustry in Colombia and the creation of a company producing cut flowers. https://intellectum.unisabana.edu.co/bitstream/handle/10818 /1688/Luz_Marina_C_rdenas_Poveda.pdf?sequence $=1$

24 Chiavenato, I. (2007). Human resources administration, human capital in organizations. Retrieved from https://www.upg.mx/wp-content/uploads/2015/10/LIBRO-12Administracion-de-recursos-humanos.-El-capital-humano.pdf

López-Rodríguez, J. A. (2018). Overdiagnosis in health sciences: A scope review for Mental Health conditions. Atencion Primaria, 5o, 65-69. https://doi.org/10.1016/j.aprim.2018.08.001

Miranda, A., \& Corica, A. (2015). The work and extracurricular activities of high school youth in early twenty-first century Argentina. In Perfiles Educativos (Vol. 37, Issue 148). Universidad Nacional Autónoma de México. https://doi.org/10.1016/j.pe.2015.11.010.

Morteruel, M., Bacigalupe, A., \& Moreno, A. (2021). Towards good governance for health: incorporating the diversity of perceptions around urban health. Gaceta Sanitaria, $x x$. https://doi.org/10.1016/j.gaceta.2020.11.003.

Núñez, M. (2017). Bauman's sociology and its rejection of the politics of closing doors and making walls. Revista Mexicana de Ciencias Políticas y Sociales, 62(230), 415-420. https://doi.org/10.1016/s0185-1918(17)30035-1.

Olmos-Suárez, P. (2018). Women's hearts seen from a sociological point of view, with a gender equality focus. Revista Colombiana de Cardiologia, 25, 3-7. 
https://doi.org/10.1016/j.rccar.2017.11.027

Ortiz, L. (2014). Ethics, work and examination: The formation of school readiness in disadvantaged social milieus. Educational Profiles, 36(143), 86-104. https://doi.org/10.1016/So1852698(14)70611-7.

Richter, J. (2013). Labor in labor law. Revista Latinoamericana de Derecho Social, 16, 179-215. https://doi.org/10.1016/s18704670(13)71967-5.

Tabet, S. (2017). Intellectual itinerary and reception of Zygmunt Bauman in France. Revista Mexicana de Ciencias Politicas y Sociales, 62(230), 305-328. https://doi.org/10.1016/So1851918(17)30026-0.

25 Zuluaga, D., \& Moncayo Orjuela, B. C. (2014). Perspectives on educational leadership: Academic women in administration*. Suma de Negocios, 5(11), 86-95. https://doi.org/10.1016/s2215910x(14)70023-0. 